Article

\title{
Role of Social and Technological Challenges in Achieving a Sustainable Competitive Advantage and Sustainable Business Performance
}

\author{
Muhammad Haseeb ${ }^{1}{ }^{(}$, Hafezali Iqbal Hussain ${ }^{1}\left(\mathbb{D}\right.$, Sebastian Kot $^{2,3, *}$ (]), \\ Armenia Androniceanu ${ }^{4,5}$ and Kittisak Jermsittiparsert ${ }^{6}$ (D) \\ 1 Taylor's Business School, Taylor's University Lakeside Campus, 1 Jalan Taylors, Subang Jaya 47500, Malaysia \\ 2 Faculty of Economic and Management Sciences, North-West University, Vaal Triangle Campus, \\ P.O. Box 1174, Vanderbijlpark 1900, South Africa \\ 3 The Management Faculty, Czestochowa University of Technology, 42.201 Czestochowa, Poland \\ 4 Administration and Public Management Faculty, The Bucharest University of Economic Studies, \\ Piața Romană, 6010374 București, Romania \\ 5 -Research Department, University of Social Sciences, 9 Sienkiewicza St., 90-113 Łódź, Poland \\ 6 Social Research Institute, Chulalongkorn University, Bangkok 10330, Thailand \\ * Correspondence: sebacat@zim.pcz.czest.pl; Tel.: +48-34-3250-345
}

Received: 17 May 2019; Accepted: 17 June 2019; Published: 11 July 2019

\begin{abstract}
In the postmodern era of industrialization, sustainable business performance is vital for success in a competitive environment. In order to attain sustainable business performance, Malaysian Small and Medium-sized Enterprises (SMEs) are facing various social and technological challenges. The objective of this study was to examine the roles of social and technological challenges in achieving a sustainable competitive advantage and sustainable business performance. To accomplish this objective, first-hand data were collected from Malaysian SMEs. Opinions of managerial staff of these SMEs were preferred regarding the roles of social and technological challenges in achieving a sustainable competitive advantage and sustainable business performance. An email survey was carried out to collect data. A total of 500 questionnaires were distributed among managerial staff of SMEs. Questionnaires were distributed by using simple random sampling. By using structural equation modeling, findings of the study revealed that social and technological challenges played major roles in boosting sustainable competitive advantage and sustainable business performance. Moreover, strategic alignment was a key in reflecting the positive roles of social and technological factors on sustainable competitive advantage. Findings of the study are beneficial for practitioners and will allow their strategies to reflect sustainable competitive advantages and sustainable business performance.
\end{abstract}

Keywords: social challenges; technological challenges; strategy alignment; competitive advantage; sustainable business performance

\section{Introduction}

In the postmodern era of industrialization, sustainable performance is vital for success in a competitive environment [1-3]. In the last decade, it has been a key goal of every organization $[4,5]$. There has been growing interest in the usage of a decision-making framework to accomplish sustainability goals in the current decade [6,7] because it is the most important part of every organization to achieve success in their objectives [8].

Sustainable performance can be defined as the harmonization of financial, social, and environmental purposes in the delivery of fundamental business actions in order to maximize value. It is the performance of a corporation in all dimensions as well as for all drivers of corporate 
sustainability [9]. Sustainable performance plays a key role in the sustainability of Small and Medium-sized Enterprises (SMEs) [10-14].

SMEs are the major sector of every country. It has important roles in the Gross Domestic Product (GDP) of every country $[15,16]$. Increases in GDP improve economic growth. In the case of Malaysian SMEs, this sector has an influencing role on the economic growth of Malaysia [17]. The Malaysian government has been trying to enhance the economic contribution of SMEs to the nation's economy. In recent years, Malaysian SMEs recorded significant contributions to the economy.

It is evident from Figure 1 that Malaysian SMEs are a major contributor to GDP. SME GDP was recorded as RM 435.1 billion (1 USD is approximately RM 4.00) in 2017, in which the service sector had major contributions (which was 59.7\%) followed by the manufacturing sector (which had $2.5 \%$ contribution). Moreover, agriculture had $11.2 \%$ contribution, the construction sector had $5.8 \%$ contribution, important duties had $1.4 \%$, and mining had $0.4 \%$ contribution to Malaysian SME GDP. Therefore, it is evident that Malaysian SMEs are crucial in increasing economic growth.
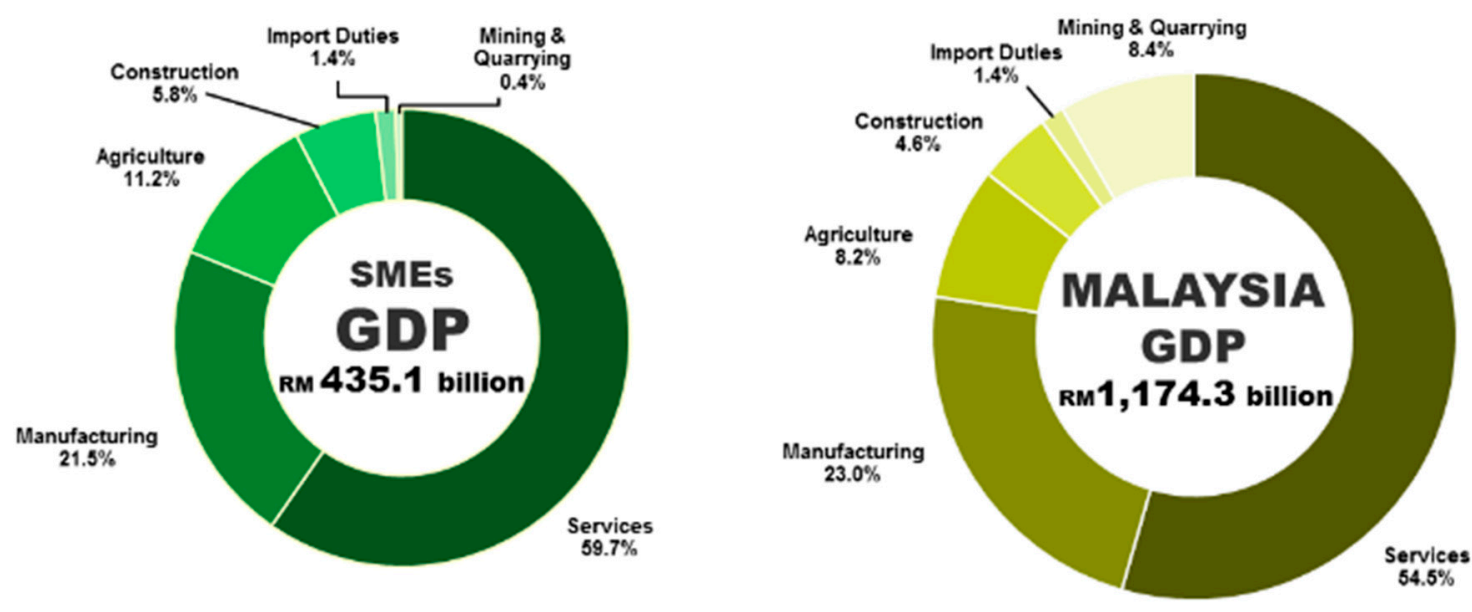

Figure 1. Percentage share of Small and Medium-sized Enterprises (SMEs) GDP and Malaysian GDP in 2017 [16].

However, Malaysian SMEs face various social and technological challenges. The term "challenge" can be described as the call to prove or justify something by companies in a competitive environment. In the context of the current study, since it is tough to survive in a competitive environment, it is a challenge for SMEs to handle technological challenges. To achieve success in a highly competitive environment, one of the challenges for SMEs is to adopt new technologies. Social challenges include social responsibility as well as values and beliefs. Negative values in companies, unconstructive beliefs of employees, and resistance to change or adoption of new technologies are due to fear of complexity in utilizing the latest technology and an absence of confidence among employees to utilize new technology to improve business performance [18]. Negative values and beliefs impact adversely on a sustainable, competitive advantage, which ultimately decreases sustainable business performance. Moreover, social responsibility is another challenge to companies in achieving smooth performance [19-22]. SMEs need to ensure better corporate responsibility to handle the growing challenges of social issues to enhance sustainable, competitive advantages; this is an important role in SME performance [23,24].

In an organization, culture is the mixture of manager perceptions regarding any problem, which is one of the important challenges. For instance, if managers of an organization do not trust that information technology (IT) is strategic, this will reflect how they accomplish as well as deal with IT and IT challenges $[25,26]$. Therefore, IT managerial resources are the most crucial challenge. It belongs to the level of participation from IT executives and business in negotiation of contract, vendor selection, management, and implementation of IT projects. Along with the IT managerial resources, IT implementation success is crucial, which is another challenge. Adoption of new technology is always difficult [27-29]. Therefore, SMEs face various social and technological challenges 
such as social responsibility, values and beliefs, IT managerial resource and IT implementation success. Better handling of these challenges increases the sustainable competitive advantage. Sustainable competitive advantage improves sustainable business performance [30-32].

The motivation of the study centers around the above challenges as the current study focuses on providing the solution of these challenges facing by the SMEs. Because of the technological challenges, it has a vital role in attaining competitive advantage, it is also essential to achieve higher performance. In the same direction, this is one of the pioneer studies, which highlights social responsibility, values and beliefs, IT managerial resource and IT implementation success as the important technological challenges in SMEs. This is one of the pioneer studies that highlights technological challenges can be resolved through various factors. These factors playing the role in line with resource-based view (RBV) mechanism, shown in Figure 2. All the factors are addressed in Figure 3.

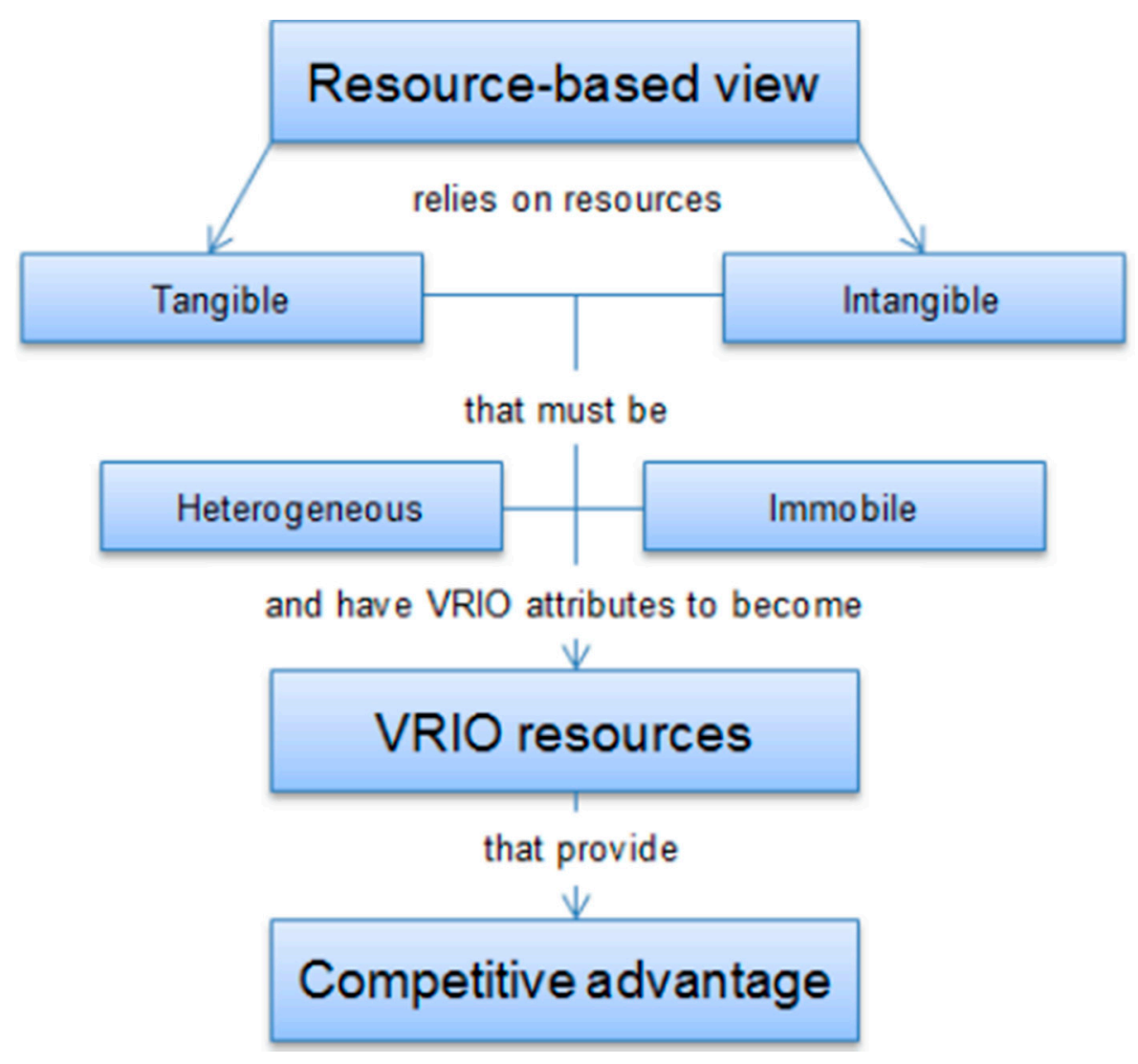

Figure 2. Resource-Based View (RBV).

Therefore, the objective of this study is to examine the role of social and technological challenges in sustainable competitive advantage and sustainable business performance. Various researchers examine sustainable business performance with different aspects [33-37]. However, most of the studies are missing the role of social and technological challenges of sustainable business performance. Figure 3 shows that how social and technological challenges play roles in achieving a sustainable competitive advantage and sustainable business performance. Thus, the current study is one of the attempts to address this literature gap. Additionally, the sub-objectives are as follows:

1. To examine the role of social responsibility in sustainable competitive advantage.

2. To examine the role of values and beliefs in sustainable competitive advantage.

3. To examine the role of IT managerial resources in sustainable competitive advantage.

4. To examine the role of IT implementation success in sustainable competitive advantage.

5. To examine the mediating role of strategic alignment. 
6. To examine the role of sustainable competitive advantage in sustainable business performance.

The current study contributes to existing knowledge by investigating the roles of social and technological challenges in achieving a sustainable competitive advantage and sustainable business performance. It investigated that strategic alignment is one of the significant factors to transform the positive effect of social and technological elements on sustainable competitive advantage. It contributed to the literature that strategic alignment is an essential factor to take maximum benefit from new technology and social factors. This study provides a comprehensive framework to enhance SMEs performance with the help of resolving social and technological challenges.

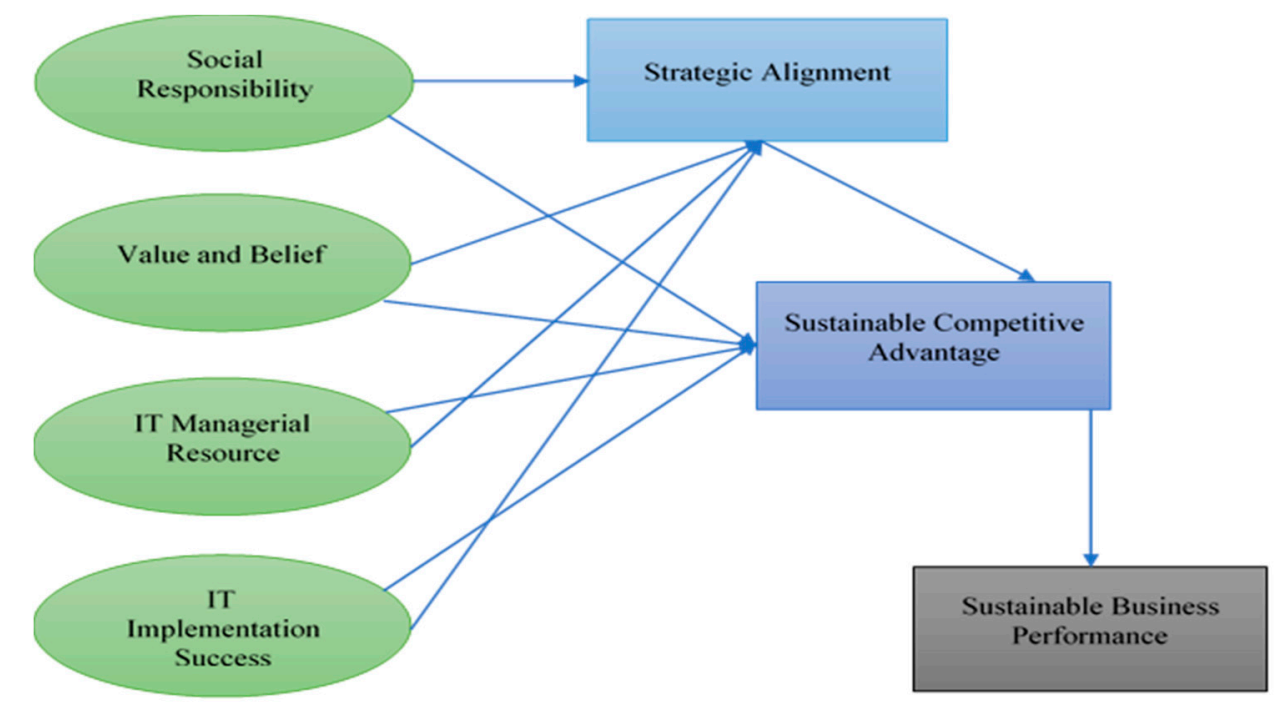

Figure 3. Theoretical framework of social and technological challenges in sustainable competitive advantage and sustainable business performance.

\section{Literature Review}

\subsection{Resource-Based View (RBV)}

The Resource-Based View (RBV) perceives that its resources fundamentally control an organization's success. These resources are named assets or capabilities. The assets can be tangible or intangible [38], though the capabilities are intangible, including abilities and information [39]. Besides, the capital equipment, learning and abilities of representatives, and firm goodwill are the resources of a firm [40]. As indicated by RBV, the principal factors in deciding the sustainable competitive advantage for a firm are its resources [40]. These general important and rare intangible resources are vital for making and keeping up a competitive advantage. Because of these particular resources, a firm progresses towards sufficiently proficient for creating and conveying creative as well as top-notch items and administrations, and it also makes a distinction among other company's products [40,41]. RBV is given in Figure 2, which shows that resources are based on tangible and intangible, which must be heterogeneous and immobile. These resources finally influence competitive advantage.

In addition, the RBV centres around the match between organizational capabilities and available opportunities. This clarifies the disappointment of visual failure of organizational systems. It turns out to be genuine where there is a mismatch between organizational capabilities and opportunities. In the present study, social and technological challenges are the resources of SMEs. Better management of social responsibility, better values and beliefs of employees, IT managerial resources and better IT implementation are the resources of the company. These resources are increasing the sustainable competitive advantage among SMEs.

Alluding to the consequences of asset-based perspective of the firm, it accentuates on the significance of resources for making and supporting competitive advantage. In this manner, 
organizations ought to have the potential for distinguishing and making appropriate utilization of their accessible asset [42]. Further to this, Barney [43] referenced that the inward and outer condition both have been significantly underscored. Consequently, organizations ought to get most refreshed data identified from candidates, markets and clients. In conclusion, the third consequence of RBV on organizational success is for organizational capabilities. The organizational capabilities incorporate people with specific range of abilities and experience, data and process, in case, if ultimately used can deliver creative results with high quality for surpassing client desires [44]. Likewise, it is entrenched that the organizational capabilities upgrade the esteem of accessible asset for their viable use $[45,46]$. As per Teece, Pisano and Shuen [39] the sustainable competitive advantage creation links with a dynamic process for organizations to develop and get the dynamic business condition. Therefore, this sustainable competitive advantage increases sustainable business performance among SMEs with the help of internal resources, including social and technological factors. Additionally, it is recommended that the improvement of dynamic capabilities procedures need to be founded on the learning along with organizational learning exercises [47,48].

Further to this, one of the complications of RBV on business success is identified with organizational capabilities. The organizational capabilities include human asset (that are skilled, capable, and experienced), data, and specific procedures that could be responsively used to deliver high-quality results, for example, enhanced business success and different advancements [44]. Corporate enterprise is a procedure, and it has stable connection with the human resource that at last, helps organizations to enhance their sustainable business performance.

Essentially, the objective of this study is to examine the roles of social and technological challenges in achieving a sustainable competitive advantage and sustainable business performance. In consistent with RBV, social and technological factors are the resources of a company, which influence positively on sustainable competitive advantage, and ultimately increase the sustainable business performance. These variables have been underpinned by the RBV theory, as suggested in the literature, shown in Figure 3.

According to RBV, the key features in determining the sustainable competitive advantage for an organization are its resources, both internal as well as external [40]. These rare, valuable, and inimitable intangible strategic resources are the engine for creating as well as sustaining competitive advantage. Because of these unique resources, a firm becomes proficient enough for producing as well as delivering innovative and high-quality products and services, and it creates a difference [41]. Moreover, the RBV emphasizes the available match between organizational capabilities as well as opportunities. This clarifies that the failure for blind imitation of organizational strategies becomes true where there is a mismatch between organizational capabilities and existing opportunities.

Makadok [42] described that the essence of RBV process is to consider the use of resources at the completest to build up the unique core competencies for the accomplishment of competitive advantage. For attaining the desired competitive strategic position, firms can develop their competencies by observing into factors such as human competencies, internal organizational strategies, regulations as well as suitable information sources [41]. In the context of this study, IT implementation, IT managerial resource, social responsibility, values and beliefs are the core competencies of any organization for a competitive advantage, which is crucial for sustainable business performance.

\subsection{Hypotheses Development}

The success of any businesses depends on having some advantages compared to their competitors. Therefore, the key objective of strategy is to attain a competitive advantage as well as performance [49,50]. For achieving this goal, specific strategies and challenges, such as social responsibility, values and beliefs, IT managerial resources, IT implementation success and strategy alignment to gain a competitive advantage in a competitive environment are needed. In any case, regardless of whether businesses are competent to pick up a competitive advantage and accomplish a more elevated amount of 
profitability, they lose this competitive advantage after some time. This is because their systems are generally duplicated.

Accomplishing a competitive advantage empowers a firm to raise effective obstructions and accomplish a sustainable competitive advantage [51]. In any case, anticipating imitation does not keep going forever. Along these lines, the firm will pick up the greatest profit by any competitive advantages. Accomplishing better development basically needs specific core values. The entrance to some competitive advantage would be essential for building this solid and separated centre [52].

As indicated by Prahalad and Hamel [46], "similar formidable" standards for item cost and quality combine to that of Western and Japanese organizations. These standards are increasingly imperative as qualifying criteria for success in the rivalry and imperative as sources of sustainable competitive advantage. They further recommend that the genuine wellspring of sustainable competitive advantage is identified with an organization's capacity to unite innovations and aptitudes generation in abilities that enable the business to adjust rapidly to growing openings. Kanterholds $[53,54]$ proposed that organizations must constantly concentrate on their skills, put resources into improvement, and de-underline exercises that do not add value. Therefore, they will be fruitful. Achievement in changing the conditions is ensured by characterizing the capabilities and sorting out it to help and expand them.

Onkvisit and Shaw [55] argue that organization in the previous decades had contributed to turning into lean and adaptable to react quickly to condition and market changes. They likewise benchmarked continuously to accomplish the best practice and outsourced to accomplish efficiencies. The companies are prominent for inferring competitive advantage by operational adequacy. These ventures have blown-up in securing sustainable competitive advantage despite the fact that they have prevailed with regards to accomplishing operational enhancements, effectiveness and competitive advantage [55]. To gain sustainable competitive advantage, social responsibility, values and beliefs, IT managerial resources, IT implementation success and strategy alignment are needed.

Various researchers work on the social responsibility of companies [56-61]; however, these studies misses with the roles of achieving a competitive advantage and sustainable business performance. It is found that the social responsibility of organization affects sustainable competitive advantage [62-65]. Better social responsibility achievement increases the competitive advantage of companies. However, lose control of social responsibility decreases the competitive advantage.

While the job of business, society continues changing after some time, there has been no concurrence on what social responsibility remains among the spectators or to what degree is the limit of social responsibility as it is interpreted differently by individuals. What social responsibility shows, among experts that actualizes it inside their organizations contrasts from what it intends to experts trying to establish it as a discipline [66].

Organization's responsibilities in creating nations are characterized distinctively dependent on the social (particularly national setting) [66]. For instance, social responsibility among organizations in Malaysia is halfway persuaded by religious conviction [66], in Argentina, it is halfway impacted by the monetary emergency in 2001 [67], while corporate social responsibility in South Africa centre around the issues of racial imbalance because of the one of a kind inheritance of politically-sanctioned racial segregation. Malaysian organizations generally centre on beneficent exercises that revolve around the Muslim and Chinese religious occasions, while South African nations centre on the strengthening of the black individuals of the country. Thus, it may be said that corporate social responsibility or social responsibility implies distinctive things to various individuals from various countries [66]. All these factors have significant influence to gain or sustain competitive advantage.

Despite the fact that no universal definition has been available for social responsibility, yet numerous private organizations allude to social responsibility as an approach to coordinate the ecological, social and the monetary complications of their business exercises in the regularly developing business world [68,69]. Therefore, it ends up obvious for business organizations to be dependable to stay current, and it participates in-light of the differed partners. In the present 
time of modern globalization, companies and business organizations have gone past the restriction of their country state and this prevalence of the global organization past the restriction of their country has brought about an increment in the interest for greater responsibility and straightforward worldwide business [68].

Business organizations challenge to react to a trustworthy responsibility agenda [68]. Globalization and the challenge for restricted resources have kept corporate social responsibility in the focal point of discussion among business network and Government. Numerous advocates were guaranteed in the talk on corporate social responsibility in the western world, where it is guaranteed that corporate social responsibility is not a greater amount of corporate philanthropy, it is fairly an essential logic for extensive, medium and little ventures to gain comparative advantage and sustainable business performance among various companies [68]. Various studies proved that social responsibility has important roles in achieving a sustainable competitive advantage [70,71]. In line with social responsibility, values and beliefs are equally important in achieving sustainable competitive advantage.

Values and beliefs are important roles to gain sustainable competitive advantage, and these are the challenges in SMEs. The values and beliefs of organizational individuals tremendously affect numerous measurements of IT in organizations. These incorporate the method for overseeing IT in organizations. For instance, if business administrators do not trust that IT is strategic this may characterize how they oversee and manage IT-related issues [72]. This measurement is a point of worry about the values and beliefs of organizational members because it influences in achieving a sustainable competitive advantage. Values and beliefs can fundamentally shape the career, including conduct and practices. These beliefs are moulded all through one's profession dependent on the experience which one has with IT. Real impacts are probably going to originate from experience with IT both from past work environments and from current industry or the organization. Values and beliefs ought not to be mistaken for culture. While the idea of culture is present in the administration classification, actually begins from human conduct [73-76]. Culture is an idea which includes values and beliefs, yet it is additionally moulded by stories, control frameworks, structures, and legislative issues. These culture issues have vital role in shaping competitive advantage. Singular values and beliefs are, for sure, a sufficient power to affect competitive advantage. Therefore, IT issues have a relationship with values and beliefs [26] and competitive advantage.

Thus, better values and beliefs have the ability to resolve various IT challenges. Values and beliefs are one of the challenges in proper IT implementation. An attitude of organization towards new technology adoption has important challenge [77]. There values and beliefs belong to the culture of organization. Culture of the organization has a significant link with technological adoption in which attitude has essential role and has an important link with achieving a competitive advantage [78-81].

\section{H1: There is a relationship between social responsibility and sustainable competitive advantage.}

H2: There is a relationship between values and beliefs and sustainable competitive advantage.

SMEs are also facing new technological challenges including IT managerial resources and IT implementation success. Good managerial resources for IT are vital to implement new technology, which is a challenge among most of the companies. This antecedent concerns the dimension of the association from business and IT managers in seller determination, contract transaction and the executives, and the structure as well as usage of the IT projects. Freeman and Sharp [82] expressed that IT achievement, for the most part, reflects a successful connection between business supervisors and IT, and it is the principal supporter of effective seller relations. Chan et al. [83] clarified that IT partners are bound to be trusted and counselled in the basic leadership process. They turn out to be increasingly mindful of both existing and new business openings and have the reasonable learning not merely in working inside existing markets, yet also with a recently developing business sector which has an impact on competitive advantage. A prior examination by Boynton et al. [84] surveyed 
administrative IT learning of the business' tasks and systems, found that more elevated amounts of administrative IT information emphatically anticipated a higher utilization of IT resources.

Better IT managerial resources have the ability to apply technology, which increases the competitive advantage, as it is proved from the literature that IT managerial resources, including IT skills, have a positive effect on competitive advantage [85]. IT managerial resources are based on human resources and human resources have major roles in achieving a competitive advantage [86-90]. Additionally, IT implementation is crucial. Implementation of new technology is more important when compared to simply introduce new technology.

Most of the companies are facing the issues while implementing a successful IT unit. Successful history of IT unit offers reliability to the IT unit and makes a complementary view of IT in the best administration [91-93]. Likewise, it basically adds to the contribution of business directors in the arranging procedure [94]. For the arrangement of business designs, two vital critical success factors found those are the confirmation of best administration in the IT division, and dependable administrations [95]. Teo and Ang [95] hypothesized that confirmation of best administration in IT builds their commitment to the strategic utilization of IT, making them bound to distribute appropriate asset for the arranging and improvement of IT applications.

H3: There is a relationship between IT managerial resources and sustainable competitive advantage.

H4: There is a relationship between IT implementation success and sustainable competitive advantage.

Consistent with social and new technological challenges, strategic alignment is one of the procedures and the outcome of connecting an organization's structure as well as resources with its strategy and certain business environment. Strategic alignment comprises of matching skills to achieve certain goals regarding the plan of organization. It is a comprehensive procedure, which includes strategy, people, rewards and structure. It is a process which in line the organization structure with the business model that has a significant link with achieving a sustainable competitive advantage. Strategic alignment is shown in Figure 4.

The alignment between the business strategy and its strategic decisions is a noticeable area of intention that stays on a high priority business, IT issues in which business and IT executives suffer [96]. IT-business strategic alignment is viewed as a very imperative issue especially when IT turns into a fundamental piece of the business and is used for the utilization of unique business capabilities, consolidate organizations, rebuild businesses, and facilitate worldwide competition [72].

Today's Businesses are confronting a consistently expanding competition both at the local and worldwide level. Thus, it turns into a basic necessity for an organization to comprehend the nature of making a competitive advantage. A few researchers $[97,98]$ showed that the literature proposes that the organizations could be competitive just if there is an alignment between the business and data innovation of the organizations. Therefore, alignment of strategies is most important to gain competitive advantage.

Various social and technological challenges in SMEs such as social responsibility, values and beliefs, IT managerial resources and IT implementation success can be managed through proper strategy alignment. IT managerial resources and IT implementation success challenge can be managed by allocating skilled people, and social issues can also be handled with aligning better strategies, which automatically increases the sustainable competitive advantage. As it is proved by different studies that strategic alignment and sustainable competitive advantage have a significant relationship [99-102]. 


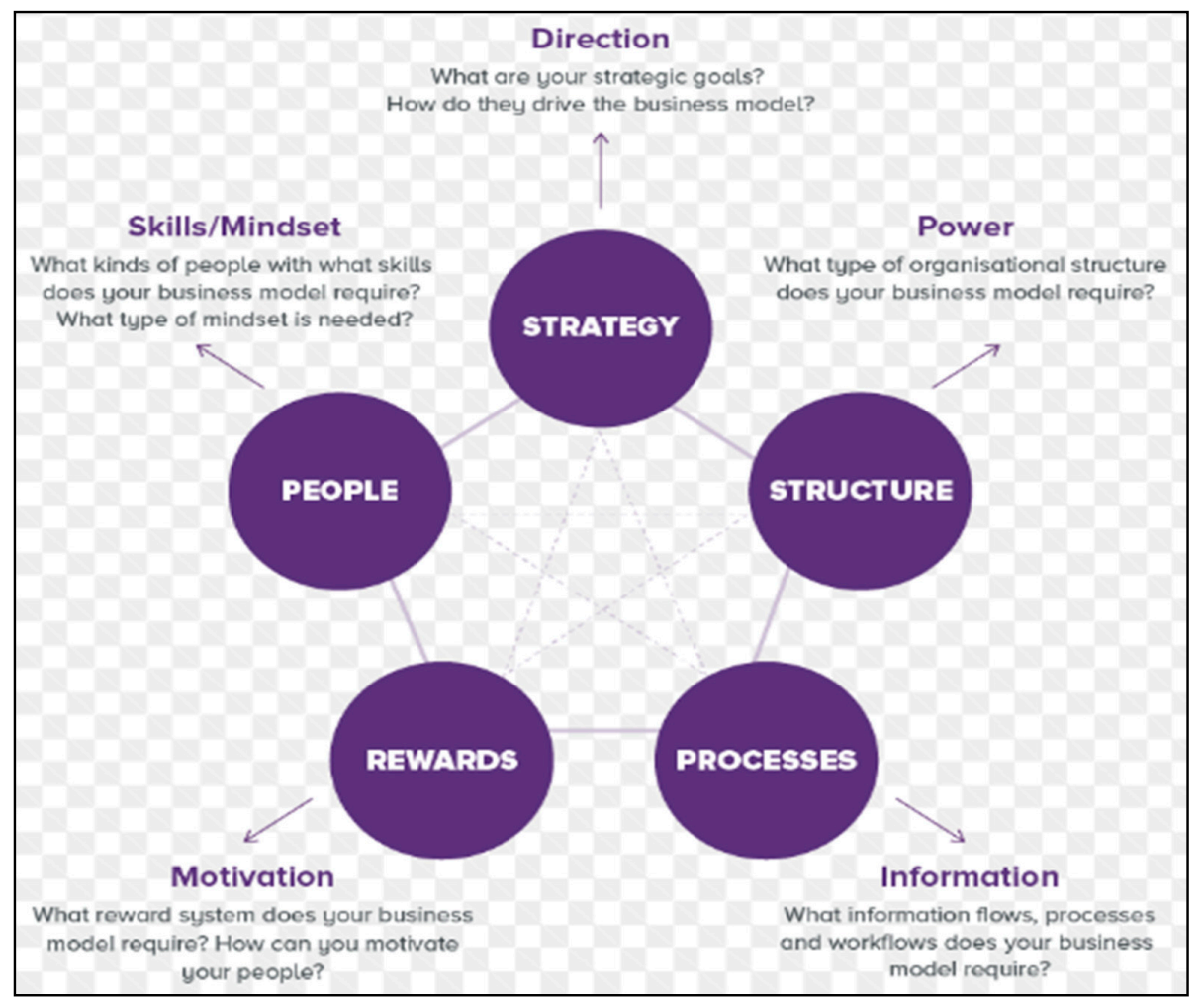

Figure 4. Strategic Alignment.

In line with the above lines, increases in sustainable competitive advantage directly improve sustainable business performance. Literature suggested that companies should focus on competitive advantage in a competitive environment with a sustainable business performance at a satisfactory level. As it is found by various studies that sustainable competitive advantage has a significant relationship with sustainable business performance [103-105]. Therefore, from the above discussion, the following hypotheses are proposed;

H4: There is a relationship between social responsibility and strategy alignment.

H5: There is a relationship between values and beliefs and strategy alignment.

H6: There is a relationship between IT managerial resources and strategy alignment.

H7: There is a relationship between IT implementation success and strategy alignment.

H8: Strategy alignment mediates the relationship between social responsibility and sustainable competitive advantage.

H9: Strategy alignment mediates the relationship between values and beliefs, and sustainable competitive advantage.

H10: Strategy alignment mediates the relationship between IT managerial resources and sustainable competitive advantage.

H11: Strategy alignment mediates the relationship between IT implementation success and sustainable competitive advantage.

H12: There is a relationship between strategy alignment and sustainable competitive advantage.

H13: There is a relationship between sustainable competitive advantage and sustainable business performance.

\section{Methodology}

The present study implemented a quantitative research approach for measuring the structural relationship among various proposed latent variables. Using PLS-SEM under SmartPLS 3.0 (Developed 
by: Christian M. Ringle, Sven Wende, Jan-Michael Becker; Hamilton, New Zealand) thirteen hypotheses were developed based on RBV theory. The research design based on cross-sectional was implemented in the study in which the data were collected once. This process was followed with the help of data analysis as well as statistical understandings while making inferences related to the particular population to conduct the present study at one point in time. Thus, the present study preferred to use cross-sectional research design rather than longitudinal because of the reason of resource constraints such as money and time $[106,107]$.

The managerial staff of these SMEs was preferred to get an opinion regarding the roles of social and technological challenges in achieving a sustainable competitive advantage and sustainable business performance. An email survey was preferred to collect the data. First of all, the email addresses were collected from SMEs. Questionnaires were sent to them via email. A brief introduction of the study covering the objective was also attached in email. It was insured to them that the response will remain confidential and will be used for this research study.

Total of 500 questionnaires was sent to the managerial employees of Malaysian SMEs. From these questionnaires, 190 were returned, and 8 questionnaires were incomplete. Thus, 8 questionnaires were excluded from the study and 182 were used to analyse the collected data. The response rate is shown in Table 1. The total response rate is $36.4 \%$. According to Sekaran and Bougie [108,109], a 30\% response rate is sufficient in case of email survey.

Table 1. Response from respondents.

\begin{tabular}{cc}
\hline Response & Frequency/Rate \\
\hline Questionnaires distributed & 500 \\
\hline Questionnaires returned & 190 \\
\hline Valid questionnaires & 182 \\
\hline Response rate & $38 \%$ \\
\hline Response rate after data entry & $36.4 \%$ \\
\hline
\end{tabular}

Measures

All the measures were adapted from previous studies. Scale for values and belief was adapted from Grindley [110], and it is measured with the help of six items. Strategic alignment measures were adapted from Pierce [111] and measured with six items. Moreover, IT implementation success measured with the help of five items, which were adapted from Sabherwal and Kirs [112]. Six items were used to measure sustainable competitive advantage and adapted from De Villiers [113]. Items for IT managerial resource was adapted from Nelson and Cooprider [114]. Items for corporate social responsibility were adapted from Hamid and Atan [115]. Finally, measures for sustainable business performance were adapted from Nawanir [116]. The operationalization of all the variables is shown in the Appendix A in which all the scale items are provided.

\section{Research Analysis and Results}

It is indicated by Chin and Newsted [117] PLS is appropriate for research where (a) the theoretical model is new or not very much framed (b) the model is generally complex with various variables as well as structural paths. It is likewise helpful when the objective of the research is to predict relationships. The PLS path modeling $[117,118]$ has been utilized in the present investigation using Smart PLS 3.0 [119]. The present study considered that PLS is appropriate for different reasons. Because PLS is like conventional regression procedure, it offers an advantage to assess the connection between variables (structural model) and the relationship among constructs (the measurement model) at the same time [120-122]. 
By considering the above recommendations, this study has used PLS-SEM to achieve the major objective of this study. PLS-SEM is based on different steps which are recommended by Henseler et al. [123], and all these steps are compiled by Hameed et al. [124] as shown in Figure 5.

Confirmatory factor analysis (CFA) is shown in Figure 6. In statistics, confirmatory factor analysis (CFA) is a special form of factor analysis, most commonly used in social sciences research. It is used to test whether measures of a construct are consistent with a researcher's understanding of the nature of that construct (or factor). As such, the objective of confirmatory factor analysis is to test whether the data fit a hypothesized measurement model. It is found that all the items have factor loadings above 0.5 , as suggested by Hair et al. [125]. Confirmatory factor analysis is shown in Figure 6 and Table 2. Results of measurement model are shown in Tables 3 and 4. Table 3 depicts that all the constructs have composite reliability is above 0.7. It is evident that the average variance extracted [47] is also higher than 0.5 , which proves convergent validity, as suggested by Hair Jr et al. [126]. Furthermore, heterotrait-monotrait ratio is used to test the discriminant validity, which is shown in Table 4. While examining heterotrait-monotrait ratio, all the values should be less than 0.9 .

In the next step of PLS-SEM, the significance of structural Model was assessed. It is highlighted in Figure 7. In this procedure, the bootstrapping technique with the help of PLS is utilized to examine the beta value and $t$-value. Minimum 1.96 threshold level of $t$-value is considered to check the relationship between independent and dependent variables. Figure 6 shows the direct effect of all variables, including mediating variables. Table 5 highlights the results of direct hypotheses.

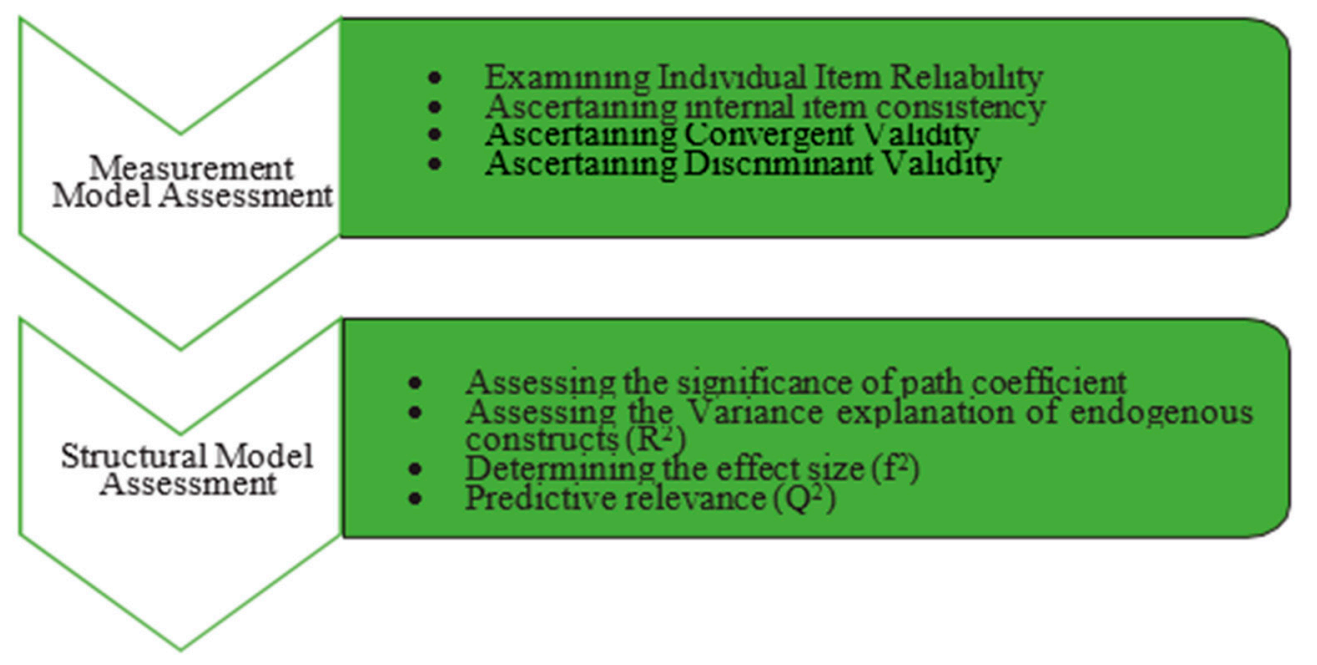

Figure 5. PLS-SEM Steps. 


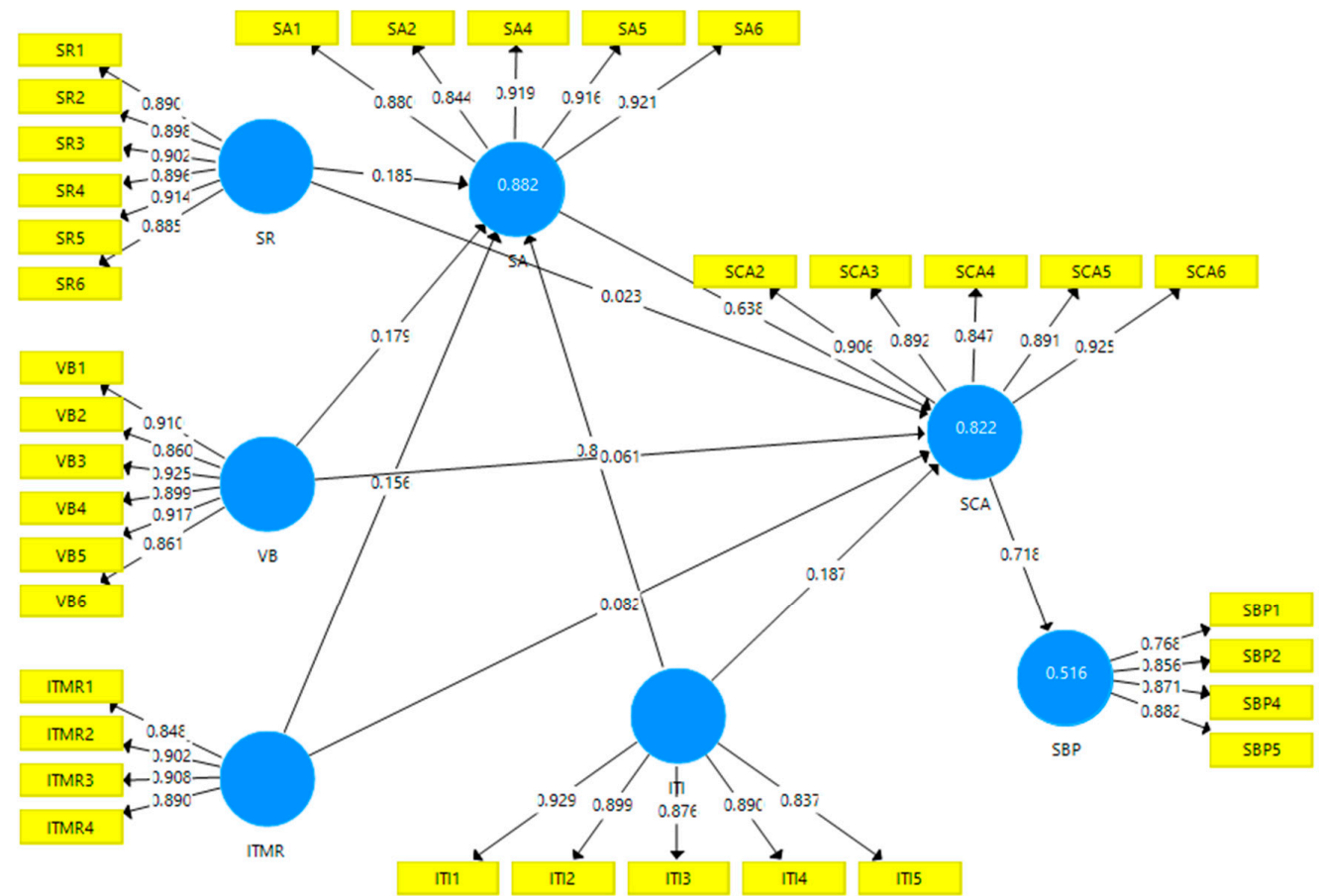

Figure 6. Confirmatory Factor Analysis.

Table 2. Factor Loadings.

\begin{tabular}{|c|c|c|c|c|c|c|c|}
\hline Variables Item & ITI & ITMR & SA & SBP & SCA & SR & VB \\
\hline ITI1 & 0.929 & & & & & & \\
\hline ITI2 & 0.899 & & & & & & \\
\hline ITI3 & 0.876 & & & & & & \\
\hline ITI4 & 0.89 & & & & & & \\
\hline ITI5 & 0.837 & & & & & & \\
\hline ITMR1 & & 0.848 & & & & & \\
\hline ITMR2 & & 0.902 & & & & & \\
\hline ITMR3 & & 0.908 & & & & & \\
\hline ITMR4 & & 0.89 & & & & & \\
\hline SA1 & & & 0.88 & & & & \\
\hline SA2 & & & 0.844 & & & & \\
\hline SA4 & & & 0.919 & & & & \\
\hline SA5 & & & 0.916 & & & & \\
\hline SA6 & & & 0.921 & & & & \\
\hline SBP1 & & & & 0.768 & & & \\
\hline SBP2 & & & & 0.856 & & & \\
\hline SBP4 & & & & 0.871 & & & \\
\hline SBP5 & & & & 0.882 & & & \\
\hline SCA2 & & & & & 0.906 & & \\
\hline SCA3 & & & & & 0.892 & & \\
\hline SCA4 & & & & & 0.847 & & \\
\hline SCA5 & & & & & 0.891 & & \\
\hline SCA6 & & & & & 0.925 & & \\
\hline SR1 & & & & & & 0.89 & \\
\hline SR2 & & & & & & 0.898 & \\
\hline SR3 & & & & & & 0.902 & \\
\hline SR4 & & & & & & 0.896 & \\
\hline SR5 & & & & & & 0.914 & \\
\hline
\end{tabular}


Table 2. Cont.

\begin{tabular}{|c|c|c|c|c|c|c|c|}
\hline Variables Item & ITI & ITMR & SA & SBP & SCA & SR & VB \\
\hline SR6 & & & & & & 0.885 & \\
\hline VB1 & & & & & & & 0.91 \\
\hline VB2 & & & & & & & 0.86 \\
\hline VB3 & & & & & & & 0.925 \\
\hline VB4 & & & & & & & 0.899 \\
\hline VB5 & & & & & & & 0.917 \\
\hline VB6 & & & & & & & 0.861 \\
\hline
\end{tabular}

Note: ITI = IT Implementation Success, SR = Social Responsibility, VB = Value and Belief, ITMR = IT Managerial Resource, SA = Strategic Alignment, SCA = Sustainable Competitive Advantage, SBP = Sustainable Business Performance.

Table 3. Reliability and Convergent Validity.

\begin{tabular}{ccccc}
\hline Variable & $\boldsymbol{\alpha}$ & rho_A & CV & AVE \\
\hline ITI & 0.932 & 0.933 & 0.948 & 0.786 \\
ITMR & 0.91 & 0.911 & 0.937 & 0.787 \\
SA & 0.939 & 0.94 & 0.953 & 0.804 \\
SBP & 0.868 & 0.878 & 0.909 & 0.715 \\
SCA & 0.936 & 0.939 & 0.951 & 0.796 \\
SR & 0.952 & 0.953 & 0.961 & 0.806 \\
VB & 0.951 & 0.953 & 0.961 & 0.802 \\
\hline
\end{tabular}

Note: ITI = IT Implementation Success, SR = Social Responsibility, VB = Value and Belief, ITMR = IT Managerial Resource, SA = Strategic Alignment, SCA = Sustainable Competitive Advantage, SBP = Sustainable Business Performance.

Table 4. Discriminant Validity.

\begin{tabular}{cccccccc}
\hline Variable & ITI & ITMR & SA & SBP & SCA & SR & VB \\
\hline ITI & & & & & & & \\
ITMR & 0.766 & & & & & & \\
SA & 0.893 & 0.794 & & & & & \\
SBP & 0.79 & 0.739 & 0.833 & & & & \\
SCA & 0.823 & 0.778 & 0.758 & 0.767 & & & \\
SR & 0.764 & 0.878 & 0.755 & 0.692 & 0.737 & & \\
VB & 0.737 & 0.89 & 0.77 & 0.695 & 0.752 & 0.852 & \\
\hline
\end{tabular}

Table 5. Direct effect results.

\begin{tabular}{cccccc}
\hline Relationship & $\boldsymbol{\beta}$ & STDEV & $\boldsymbol{t}$-Statistics & $\boldsymbol{p}$-Values & $\mathbf{f}^{2}$ \\
\hline $\mathrm{ITI} \rightarrow$ SA & 0.828 & 0.053 & 15.705 & 0.000 & 0.951 \\
$\mathrm{ITI} \rightarrow$ SCA & 0.187 & 0.091 & 2.056 & 0.040 & 0.025 \\
$\mathrm{ITMR} \rightarrow$ SA & 0.156 & 0.038 & 4.137 & 0.000 & 0.024 \\
$\mathrm{ITMR} \rightarrow$ SCA & 0.082 & 0.082 & 4.697 & 0.000 & 0.004 \\
$\mathrm{SA} \rightarrow$ SCA & 0.638 & 0.099 & 6.42 & 0.000 & 0.270 \\
$\mathrm{SCA} \rightarrow$ SBP & 0.718 & 0.044 & 16.155 & 0.000 & 0.852 \\
$\mathrm{SR} \rightarrow$ SA & 0.185 & 0.047 & 3.931 & 0.000 & 0.039 \\
$\mathrm{SR} \rightarrow$ SCA & 0.023 & 0.011 & 2.16 & 0.039 & 0.001 \\
$\mathrm{VB} \rightarrow$ SA & 0.179 & 0.052 & 3.472 & 0.003 & 0.034 \\
$\mathrm{VB} \rightarrow$ SCA & 0.061 & 0.025 & 2.55 & 0.012 & 0.002 \\
\hline
\end{tabular}

Note: $\quad$ ITI = IT Implementation Success, $\mathrm{SR}=$ Social Responsibility, VB = Value and Belief, ITMR = IT Managerial Resource, SA = Strategic Alignment, SCA = Sustainable Competitive Advantage, SBP = Sustainable Business Performance. 


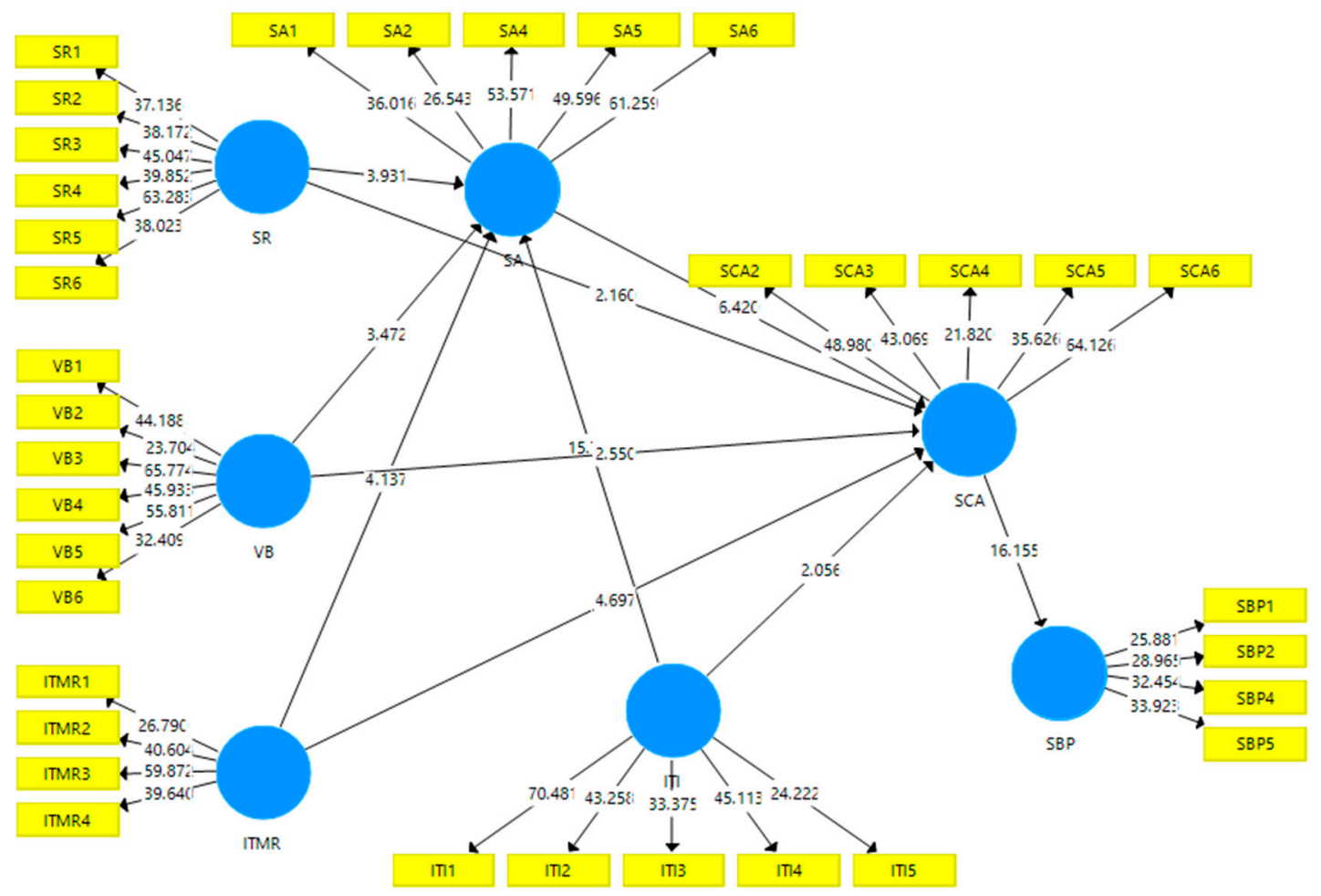

Figure 7. Results for Direct Hypotheses Test.

The relationship between social responsibility and sustainable competitive advantage found significant and positive with $t$-value 2.16 and $\beta$ value 0.023 . The relationship between values and beliefs with sustainable competitive advantage found significant and positive with $t$-value 2.55 and $\beta$ value 0.061 . Moreover, IT managerial resources also have a positive effect on sustainable competitive advantage with $t$-value 4.137 and $\beta$ value 0.156 . Consistent with these results, the relationship of IT implementation success and sustainable competitive advantage found $t$-value 2.056 and $\beta$ value 0.187. Therefore, all these variables have a positive effect on sustainable competitive advantage. Additionally, the direct effect of social responsibility, values and beliefs, IT managerial resources and IT implementation has a significant positive effect on strategy alignment with $\mathrm{t}$-value 3.931 and $\beta$ value $0.185, t$-value 3.472 and $\beta$ value $0.179, t$-value 4.137 and $\beta$ value $0.156, t$-value 15.705 and $\beta$ value 0.828 , respectively. In line with these findings, it is found that strategy alignment has positive roles in achieving a sustainable competitive advantage with $t$-value 6.42 and $\beta$ value 0.638 . Moreover, the same results are found in case of sustainable competitive advantage and sustainable business performance with $t$-value 16.155 and $\beta$ value 0.718 . These results have supported all direct hypotheses. Moreover, indirect effect is highlighted in Table 6.

Table 6. Indirect Effect.

\begin{tabular}{lccccc}
\hline Relationship & $\begin{array}{c}\text { Original Sample } \\
(\mathbf{O})\end{array}$ & Sample Mean (M) & $\begin{array}{c}\text { Standard Deviation } \\
\text { (STDEV) }\end{array}$ & $\begin{array}{c}t \text {-Statistics } \\
(\mid \mathrm{O} / \mathrm{STDEV})\end{array}$ & $\boldsymbol{p}$-Values \\
\hline $\mathrm{ITI} \rightarrow \mathrm{SA} \rightarrow \mathrm{SCA}$ & 0.528 & 0.515 & 0.089 & 5.954 & 0 \\
$\mathrm{ITMR} \rightarrow \mathrm{SA} \rightarrow \mathrm{SCA}$ & 0.1 & 0.101 & 0.003 & 3.388 & 0.003 \\
$\mathrm{SR} \rightarrow \mathrm{SA} \rightarrow \mathrm{SCA}$ & 0.118 & 0.119 & 0.05 & 2.31 & 0.014 \\
$\mathrm{VB} \rightarrow \mathrm{SA} \rightarrow \mathrm{SCA}$ & 0.114 & 0.116 & 0.068 & 1.642 & 0.073 \\
\hline
\end{tabular}

Apart from direct results, it is found that indirect effect through strategy alignment is significant in case of social responsibility and sustainable competitive advantage with $t$-value 2.31 and $\beta$ value 0.118 . The indirect effect also found significant in case of IT managerial resources and IT implementation success $t$-value 3.388 and $\beta$ value $0.1, t$-value 5.954 and $\beta$ value 0.528 , respectively. However, the indirect 
effect between values and beliefs, and sustainable competitive advantage found insignificant, which did not support H9.

R-square $\left(R^{2}\right)$ and predictive relevance $\left(Q^{2}\right)$ is shown in Tables 7 and 8 , respectively. The r-square value for sustainable business performance is 0.321 , which weaks as per recommendations of Chin [127]; however, it is acceptable. Thus, all the exogenous latent variables are expected to bring $32.1 \%$ change in sustainable business performance. Predictive relevance $\left(\mathrm{Q}^{2}\right)$ shows that the quality of model has also achieved the satisfactory threshold level.

Table 7. R-Square $\left(\mathrm{R}^{2}\right)$.

\begin{tabular}{cc}
\hline Latent Variable & $\mathbf{R}^{\mathbf{2}}$ \\
\hline Strategy Alignment (SA) & 0.882 \\
Sustainable Business Performance (SBP) & 0.516 \\
Sustainable Competitive Advantage (SCA) & 0.822 \\
\hline
\end{tabular}

Table 8. Predictive Relevance $\left(\mathrm{Q}^{2}\right)$.

\begin{tabular}{cccc}
\hline Latent Variable & SSO & SSE & Q $^{\mathbf{2}}$ (1 - SSE/SSO) \\
\hline Strategy Alignment (SA) & 910 & 297.46 & 0.673 \\
Sustainable Business Performance (SBP) & 728 & 494.389 & 0.321 \\
Sustainable Competitive Advantage (SCA) & 910 & 348.677 & 0.617 \\
\hline
\end{tabular}

\section{Discussions}

Findings revealed that social and technological challenges are most crucial to promote sustainable competitive advantage and sustainable business performance. Results of the analysis show that social responsibility has a positive association with sustainable competitive advantage. Various other studies have also revealed the same fact [32,128-130]. Moreover, values and beliefs have also found a positive relationship with sustainable competitive advantage. These findings are consistent with Al-Majali [18]. Therefore, the present study shows that social challenges such as values and beliefs, and social responsibility promote sustainable competitive advantage. SMEs management should focus on to resolve these social challenges to increase and sustain competitive advantage.

In case of technological challenges, it is revealed that IT managerial resources and IT implementation success help to sustain competitive advantage. IT managerial resources have a positive association with sustainable competitive advantage as revealed by other studies such as Byrd and Turner [131], and Al-Majali [18]. Furthermore, IT implementation success also has a significant positive effect on sustainable competitive advantage. As it is found by Dehning and Stratopoulos [132] that IT enables strategy for implementation of technology has positive role in sustainable competitive advantage. Therefore, both IT managerial resources and IT implementation success has important roles in achieving sustainable competitive advantage. Better IT implementation and IT managerial skills increase the sustainable competitive advantage. Thus, SMEs must ensure better IT skills and better IT implementation success.

Moreover, strategy alignment has key role in improving the positive effect of social and technological factors on sustainable competitive advantage. Strategy alignment positively mediates the relationship between social, technological factors and sustainable competitive advantage. Therefore, strategy alignment is required to take maximum benefits from social and technological factors.

After analysing the social and technological factors, it is revealed that a combination of all these factors with strategy alignment and the sustainable competitive advantage increase sustainable business performance, as it is proved by the present study that the competitive advantage increases sustainable business performance. It is also revealed by the prior studies carried out in various countries with different environment [30,31,133-135]. 


\section{Conclusions}

The present study majorly focuses on sustainable business performance among Malaysian SMEs. The objective of this study is to examine the roles of social and technological challenges in achieving a sustainable competitive advantage and sustainable business performance. Additionally, the mediating role of strategy alignment has also been examined between social challenges, technological challenges and sustainable competitive advantage.

Social and technological challenges have major importance for sustainable business performance. Social and technological challenges such as social responsibility, values and beliefs, IT managerial resources and IT implementation success has key contribution to boosting sustainable competitive advantage among SMEs through strategy alignment. Strategy alignment has a vital role in shifting the positive effect of social and technological factors on sustainable competitive advantage. Better strategy alignment helps SMEs to gain sustainable competitive advantage through social and technological factors. Finally, sustainable competitive advantage increases the sustainable business performance of SMEs. Therefore, it is recommended to the Malaysian SMEs to focus on social and technological challenges. Mainly, SMEs should focus on strategy alignment to boost sustainable competitive advantage and sustainable business performance. SMEs should focus on improving social responsibility, values and beliefs, IT managerial resources and IT implementation success for success in achieving sustainable business performance.

\subsection{Implications of the Study}

In this study, IT-business strategic alignment has been considered uniquely and measured from numerous perspectives with the mediation effect. Notably, there is little research on the impact of fits on the firm's sustainable competitive advantage in SMEs. The present study has also stated that the new conceptualization of IT-business strategic alignment offerings have higher insights into the conditions of alignment in terms of the antecedent variables, and the consequences in terms of the mediating procedures. Consequently, it is expected that this contribution will deliver valuable insight into academia.

Findings of the study are beneficial for practitioners while making the strategies related to sustainable competitive advantage and sustainable business performance. The present provides roadmap for SMEs to develop a framework with the combination of social factors, new technological factors and strategy alignment to increase the sustainability in achieving a firm's competitive advantage and business performance. From the study, SMEs can take help to improve the strategic alignment, which automatically boosts the positive roles of social and technological factors in achieving a sustainable competitive advantage and sustainable business performance. Therefore, while making strategies, this study provides valuable insights.

\subsection{Limitations and Future Directions}

The current study is limited to the Malaysian SMEs; therefore, the results cannot be generalized to other countries, because it is the difference between the social and technological challenges in each market or country. Moreover, the company environment is also different in each country. Thus, for more precise results, the sample of the study should include other developing countries like Malaysia. The present study is limited to quantitative research techniques; the interviews of SMEs managers through qualitative research may improve the findings. Moreover, this study followed the cross-sectional research design. However, longitudinal research design could be more beneficial to achieve the objectives. Finally, this study is only limited to the four social and technological challenges; thus, future research should include other challenges.

Author Contributions: M.H. has worked on the original idea. M.H. has performed the detailed conceptualization and investigation of this research. H.I.H. has finalized the methodology and data analysis of this research. S.K. has performed the write up of this project including the writing of original draft. S.K. has performed the data 
collection and data analysis. A.A. has written the final draft and done the review, proof reading and editing for final submission. K.J. has coordinated the methodology and data analysis stage of this research project.

Funding: This research received no external funding.

Conflicts of Interest: The authors declare no conflict of interest.

\section{Appendix A}

Scale Items

Social Responsibility

1. Our organization considers general environmental considerations by using technology.

2. Our organization provides environmental education programs, awards and studies to protect the environment by the inappropriate use of technology.

3. Our organization donates to community groups and charitable bodies.

4. Our organization provides funding scholarship programs or activities for technology use.

5. Our organization sponsors communities' programs and activities.

6. Our organization sponsors public health, sporting and recreational projects.

\section{Values and Beliefs}

1. Managers have trusts of their knowledge towards IT implementation specialist.

2. Managers trust the knowledge possessed by IT implementation specialists.

3. IT implementation for experts must be responsible for consolidating their organizations.

4. Managers comprehend IT implementation terminology well at all levels.

5. IT implementation enhances their productivity among managers.

6. It is considered that values and beliefs are key to strategic alignment.

\section{IT Managerial Resource}

1. Business managers in your company understand problems, tasks, and roles of the IT department.

2. Business managers in your company understand the accomplishments of the IT department.

3. IT managers in your company understand the work environment of the business functions.

4. IT managers in your company understand the activities of the business functions.

\section{IT Implementation Success}

1. IT implementation managers will be kept updated with strategic business plan.

2. IT implementation affects the efficiency/ effectiveness in decision making.

3. IT implementation will save expenditures of running an operation.

4. Top management provides internal training.

5. New products and services introduced in my company are based on advances in information technology.

\section{Strategy Alignment}

1. Our IT planners are aware of the firm's objectives, business strategies, and long-term goal.

2. Our firm's business plans offer clear directions for IT planning.

3. Our IT managers participate in strategic business planning.

4. Our IT and business planners interact closely in the formulation of the IT strategic plan.

5. Our IT strategy is derived from business strategy.

6. Our business and IT strategies are fully integrated and developed together. 


\section{Sustainable Competitive Advantage}

1. My organization gives attention to develop discovered ideas into new services, processes, and procedures.

2. My organization introduces services that are new to the market it serves.

3. Preferred market positioning can contribute to competitive advantages in the market place.

4. Access to superior limit resources can contribute to competitive advantages in the market place.

5. Exploiting unlimited resources can contribute to competitive advantages in the market place.

6. Access to superior competencies and capabilities can contribute to competitive advantages in the marketplace.

\section{Sustainable Business Performance}

1. Net profit margin of our organization increased.

2. Return on investment of our organization increased.

3. Profitability growth has been outstanding.

4. Profitability has exceeded our competitors.

5. Overall financial performance has exceeded competitors.

\section{References}

1. Mahdi, O.R.; Nassar, I.A.; Almsafir, M.K. Knowledge management processes and sustainable competitive advantage: An empirical examination in private universities. J. Bus. Res. 2019, 94, 320-334. [CrossRef]

2. Zhai, Y.-M.; Sun, W.-Q.; Tsai, S.-B.; Wang, Z.; Zhao, Y.; Chen, Q. An Empirical Study on Entrepreneurial Orientation, Absorptive Capacity, and SMEs' Innovation Performance: A Sustainable Perspective. Sustainability 2018, 10, 314. [CrossRef]

3. Ferreira, J.; Coelho, A.; Moutinho, L. Dynamic capabilities, creativity and innovation capability and their impact on competitive advantage and firm performance: The moderating role of entrepreneurial orientation. Technovation 2018. [CrossRef]

4. Fauzi, N.S.; Zainuddin, A.; Nawawi, A.H.; Johari, N. A Pilot Framework of Corporate Real Estate Sustainable Performance Measurement (CRESPM). Int. J. Acad. Res. Bus. Soc. Sci. 2018, 8, 725-739.

5. Chou, S.-F.; Horng, J.-S.; Liu, C.-H.; Gan, B. Explicating restaurant performance: The nature and foundations of sustainable service and organizational environment. Int. J. Hosp. Manag. 2018, 72, 56-66. [CrossRef]

6. Gong, M.; Simpson, A.; Koh, L.; Tan, K.H. Inside out: The interrelationships of sustainable performance metrics and its effect on business decision making: Theory and practice. Resour. Conserv. Recycl. 2018, 128, 155-166. [CrossRef]

7. Androniceanu, A.; Popescu, C.R. An Inclusive Model for an Effective Development of the Renewable Energies Public Sector. Adm. Public Manag. Rev. 2017, 28, 81-96.

8. Jiang, Q.; Liu, Z.; Liu, W.; Li, T.; Cong, W.; Zhang, H.; Shi, J. A principal component analysis based three-dimensional sustainability assessment model to evaluate corporate sustainable performance. J. Clean. Prod. 2018, 187, 625-637. [CrossRef]

9. Sebhatu, S.P. Sustainability performance measurement for sustainable organizations: Beyond compliance and reporting. In Proceedings of the 11th QMOD Conference. Quality Management and Organizational Development Attaining Sustainability from Organizational Excellence to SustainAble Excellence, Helsingborg, Sweden, 20-22 August 2008; pp. 75-87.

10. Moore, S.B.; Manring, S.L. Strategy development in small and medium sized enterprises for sustainability and increased value creation. J. Clean. Prod. 2009, 17, 276-282. [CrossRef]

11. O'Gorman, C. The sustainability of growth in small-and medium-sized enterprises. Int. J. Entrep. Behav. Res. 2001, 7, 60-75. [CrossRef]

12. Masurel, E. Why SMEs invest in environmental measures: Sustainability evidence from small and medium-sized printing firms. Bus. Strategy Environ. 2007, 16, 190-201. [CrossRef] 
13. Williams, S.; Schaefer, A. Small and medium-sized enterprises and sustainability: Managers' values and engagement with environmental and climate change issues. Bus. Strategy Environ. 2013, 22, 173-186. [CrossRef]

14. Kot, S. Sustainable supply chain management in small and medium enterprises. Sustainability 2018, 10, 1143. [CrossRef]

15. Aris, N.M. SMEs: Building Blocks for Economic Growth; Department of National Statistics: Putrajaya, Malaysia, 2007.

16. Tambunan, T.T.H. Development of small and medium enterprises in a developing country: The Indonesian case. J. Enterp. Communities People Places Glob. Econ. 2011, 5, 68-82. [CrossRef]

17. Tahir, H.M.; Razak, N.A.; Rentah, F. The Contributions of Small and Medium Enterprises (SME's) on Malaysian Economic Growth: A Sectoral Analysis. In International Conference on Kansei Engineering E Emotion Research; Springer: Singapore, 2018; pp. 704-711.

18. Statistics. Percentage share of SMEs DGP and Malaysian GDP in 2017. In Department of Statistics; West Group: Eagan, Minnesota, 2017.

19. Al-Majali, D.A. Antecedents of IT-Business Alignment Factors in Influencing Sustainable Competitive Advantage. Ph.D. Thesis, Universiti Utara Malaysia, Changlun, Malaysia, 2011.

20. Harrison, J.S.; Freeman, R.E. Stakeholders, social responsibility, and performance: Empirical evidence and theoretical perspectives. Acad. Manag. J. 1999, 42, 479-485.

21. McWilliams, A.; Siegel, D. Corporate social responsibility and financial performance: Correlation or misspecification? Strateg. Manag. J. 2000, 21, 603-609. [CrossRef]

22. Mackey, A.; Mackey, T.B.; Barney, J.B. Corporate social responsibility and firm performance: Investor preferences and corporate strategies. Acad. Manag. Rev. 2007, 32, 817-835. [CrossRef]

23. Pava, M.L.; Krausz, J. The association between corporate social-responsibility and financial performance: The paradox of social cost. J. Bus. Ethics 1996, 15, 321-357. [CrossRef]

24. Longo, M.; Mura, M.; Bonoli, A. Corporate social responsibility and corporate performance: The case of Italian SMEs. Corp. Gov. Int. J. Bus. Soc. 2005, 5, 28-42. [CrossRef]

25. Sarbutts, N. Can SMEs “do" CSR? A practitioner's view of the ways small-and medium-sized enterprises are able to manage reputation through corporate social responsibility. J. Commun. Manag. 2003, 7, 340-347. [CrossRef]

26. Tanriverdi, H.; Venkatraman, N. Knowledge relatedness and the performance of multibusiness firms. Strateg. Manag. J. 2005, 26, 97-119. [CrossRef]

27. Venkatraman, N.; Tanriverdi, H. Reflecting "knowledge" in strategy research: Conceptual issues and methodological challenges. In Research Methodology in Strategy and Management; Emerald Group Publishing Limited: Bingley, UK, 2004; pp. 33-65.

28. Edmondson, A.C.; Bohmer, R.M.; Pisano, G.P. Disrupted routines: Team learning and new technology implementation in hospitals. Adm. Sci. Q. 2001, 46, 685-716. [CrossRef]

29. Leonard, D.A. Implementation as mutual adaptation of technology and organization. Manag. Knowl. Assets Creat. Innovs. 2011, 17, 429.

30. Baker, E.W.; Al-Gahtani, S.S.; Hubona, G.S. The effects of gender and age on new technology implementation in a developing country: Testing the theory of planned behavior (TPB). Inf. Technol. People 2007, 20, 352-375. [CrossRef]

31. Porter, M.E. Competitive Advantage: Creating and Sustaining Superior Performance; Simon and Schuster: New York, NY, USA, 2008.

32. Porter, M.E. Competitive Advantage: Creating and Sustaining Superior Performance; FreePress: New York, NY, USA, 1985; Volume 43, p. 214.

33. Saeidi, S.P.; Sofian, S.; Saeidi, P.; Saeidi, S.P.; Saaeidi, S.A. How does corporate social responsibility contribute to firm financial performance? The mediating role of competitive advantage, reputation, and customer satisfaction. J. Bus. Res. 2015, 68, 341-350. [CrossRef]

34. Kantabutra, S. Relating vision-based leadership to sustainable business performance: A Thai perspective. Kravis Leadersh. Inst. Leadersh. Rev. 2006, 6, 37-53.

35. Wirtenberg, J.; Lipsky, D.; Abrams, L.; Conway, M.; Slepian, J. The future of organization development: Enabling sustainable business performance through people. Organ. Dev. J. 2007, 25, P11-P22, P243-P244, P237, P227. 
36. Kristensen, K.; Westlund, A.H. Accountable business performance measurement for sustainable business excellence. Total Qual. Manag. Bus. Excell. 2004, 15, 629-643. [CrossRef]

37. Samy, M.; Odemilin, G.; Bampton, R. Corporate social responsibility: A strategy for sustainable business success. An analysis of 20 selected British companies. Corp. Gov. Int. J. Bus. Soc. 2010, 10, 203-217. [CrossRef]

38. González-Benito, J.; González-Benito, Ó. Environmental proactivity and business performance: An empirical analysis. Omega 2005, 33, 1-15. [CrossRef]

39. Collis, D.J. Research note: How valuable are organizational capabilities? Strateg. Manag. J. 1994, 15, $143-152$. [CrossRef]

40. Teece, D.J.; Pisano, G.; Shuen, A. Dynamic capabilities and strategic management. Strateg. Manag. J. 1997, 18, 509-533. [CrossRef]

41. Barney, J. Firm resources and sustained competitive advantage. J. Manag. 1991, 17, 99-120. [CrossRef]

42. Russo, M.V.; Fouts, P.A. A resource-based perspective on corporate environmental performance and profitability. Acad. Manag. J. 1997, 40, 534-559.

43. Makadok, R. Toward a synthesis of the resource-based and dynamic-capability views of rent creation. Strateg. Manag. J. 2001, 22, 387-401. [CrossRef]

44. Barney, J.B. Organizational culture: Can it be a source of sustained competitive advantage? Acad. Manag. Rev. 1986, 11, 656-665. [CrossRef]

45. Amit, R.; Schoemaker, P.J. Strategic assets and organizational rent. Strateg. Manag. J. 1993, 14, 33-46. [CrossRef]

46. Prahalad, C.K.; Hamel, G. Strategy as a field of study: Why search for a new paradigm? Strateg. Manag. J. 1994, 15, 5-16. [CrossRef]

47. Wernerfelt, B. A resource-based view of the firm. Strateg. Manag. J. 1984, 5, 171-180. [CrossRef]

48. Ulrich, D. Measuring human resources: An overview of practice and a prescription for results. Hum. Resour. Manag. 1997, 36, 303-320. [CrossRef]

49. Ulewicz, R.; Blašková, M. Sustainable development and knowledge management from the stakeholders' point of view. Pol. J. Manag. Stud. 2018, 18, 363-374. [CrossRef]

50. Day, G.S. Strategic Market Planning: The Pursuit of Competitive Advantage; West Group: Eagan Minnesota, MN, USA, 1984.

51. Porter, M.E. From competitive advantage to corporate strategy. In Managing the Multibusiness Company: Strategic Issues for Diversified Groups; Routledge: Abingdon, UK, 1996; p. 285.

52. Porter, M.E. From competitive advantage to corporate strategy. In Readings in Strategic Management; Springer: Berlin, Germany, 1989; pp. 234-255.

53. Christensen, K.; Fahey, L. Building distinctive competences into competitive advantage. Strateg. Plan. Manag. 1984, 2, 113-123.

54. Kanterholds, R.M. Change is everyone's job: Managing the extended enterprise in a globally connected world. Organ. Dyn. 1999, 27, 7-23.

55. Onkvisit, S.; Shaw, J. International Marketing: Strategy and Theory; Routledge: Abingdon, UK, 2008.

56. Hill and Jones. Strategic Management Theory; Houghton Mifflin: Boston, MA, USA, 2001.

57. Carroll, A.B. The pyramid of corporate social responsibility: Toward the moral management of organizational stakeholders. Bus. Horiz. 1991, 34, 39-48. [CrossRef]

58. Matten, D.; Moon, J. "Implicit" and "explicit" CSR: A conceptual framework for a comparative understanding of corporate social responsibility. Acad. Manag. Rev. 2008, 33, 404-424. [CrossRef]

59. Campbell, J.L. Why would corporations behave in socially responsible ways? An institutional theory of corporate social responsibility. Acad. Manag. Rev. 2007, 32, 946-967. [CrossRef]

60. Sen, S.; Bhattacharya, C.B. Does doing good always lead to doing better? Consumer reactions to corporate social responsibility. J. Mark. Res. 2001, 38, 225-243.

61. Mohr, L.A.; Webb, D.J.; Harris, K.E. Do consumers expect companies to be socially responsible? The impact of corporate social responsibility on buying behavior. J. Consum. Aff. 2001, 35, 45-72.

62. Abbott, W.F.; Monsen, R.J. On the measurement of corporate social responsibility: Self-reported disclosures as a method of measuring corporate social involvement. Acad. Manag. J. 1979, 22, 501-515.

63. Brunsæl, P. Corporate Social Responsibility as Competitive Advantage and Strategic Necessity: Loooking at Firm Vision and Stakeholder Perceptions. Master's Thesis, University of Agder, Kristiansand, Norway, 2009. 
64. Cegliński, P.; Wiśniewska, A. CSR as a Source of Competitive Advantage: The Case Study of Polpharma Group. J. Corp. Responsib. Leadersh. 2017, 3, 9-25. [CrossRef]

65. Ashkar, E.; Mohamad, R. Assessing the extent of awareness and practice of corporate social responsibility CSR in achieving competitive advantage in commercial banks working in Palestine. In Assessing the Extent of Awareness and Practice of Corporate Social Responsibility CSR in Achieving Competitive Advantage in Commerical Banks Working in Palestine; The Islamic University-Gaza: Gaza City, Palestine, 2016.

66. Ashkar, E.; Mohamad, R. Assessing the Extent of Awareness and Practice of Corporate Social Responsibility (CSR) in Achieving Competitive Advantage. In Commercial Banks Working in Palestine; The Islamic University-Gaza: Gaza City, Palestine, 2016.

67. Frynas, J.G. Beyond Corporate Social Responsibility: Oil Multinationals and Social Challenges; Cambridge University Press: Cambridge, UK, 2009.

68. Newell, P.; Muro, A. Corporate social and environmental responsibility in Argentina. J. Corp. Citizsh. 2006, 24, 49-68. [CrossRef]

69. Sharma, B. Contextualising CSR in Asia: Corporate Social Responsibility in Asian Economies; Lien Centre for Social Innovation: Singapore, 2013.

70. Rajiani, I.; Pypłacz, P. National culture as modality in managing the carbon economy in Southeast Asia. Pol. J. Manag. Stud. 2018, 18, 296-310. [CrossRef]

71. Filho, J.M.d.S.; Wanderley, L.S.O.; Gómez, C.P.; Farache, F. Strategic corporate social responsibility management for competitive advantage. Braz. Adm. Rev. 2010, 7, 294-309. [CrossRef]

72. Miron, D.; Petcu, M.; Sobolevschi, I.M. Corporate social responsibility and the sustainable competitive advantage. Amfiteatru Econ. J. 2011, 13, 162-179.

73. Peppard, J.; Ward, J. Beyond strategic information systems: Towards an is capability. J. Strateg. Inf. Syst. 2004, 13, 167-194. [CrossRef]

74. Smircich, L. Concepts of culture and organizational analysis. Adm. Sci. Q. 1983, 28, 339-358. [CrossRef]

75. Smircich, L. Organizations as shared meanings. Organ. Symb. 1983, 55, 65.

76. Smircich, L. Studying organizations as cultures. In Beyond Method: Strategies for Social Research; Sage: Beverly Hills, LA, USA, 1983; pp. 160-172.

77. Balcerzak, A. Multiple-criteria evaluation of quality of human capital in the European union countries. Econ. Sociol. 2016, 9, 11-26. [CrossRef]

78. Rice, R.E.; Aydin, C. Attitudes toward new organizational technology: Network proximity as a mechanism for social information processing. Adm. Sci. Q. 1991, 36, 219-244. [CrossRef]

79. Al-Jumeily, D.; Hussain, A. The impact of cultural factors on technology acceptance: A technology acceptance model across eastern and western cultures. Int. J. Enhanc. Res. Educ. Dev. 2014, 4, 37-62.

80. Özbilen, P. The Impact of Natural Culture on New Technology Adoption by Firms: A Country Level Analysis. Int. J. Innov. Manag. Technol. 2017, 8, 299-305.

81. Luu, T.T.; Venkatesh, S. Organizational culture and technological innovation adoption in private hospitals. Int. Bus. Res. 2010, 3, 144-153. [CrossRef]

82. Au, A.Ka.; Enderwick, P. A cognitive model on attitude towards technology adoption. J. Manag. Psychol. 2000, 15, 266-282.

83. Freeman, C.; Sharp, M. Technology and the Future of Europe: Global Competition and the Environment in the 1990s; Burns \& Oates: London, UK, 1991.

84. Chan, Y.E.; Sabherwal, R.; Thatcher, J.B. Antecedents and outcomes of strategic IS alignment: An empirical investigation. IEEE Trans. Eng. Manag. 2006, 53, 27-47. [CrossRef]

85. Boynton, A.C.; Zmud, R.W.; Jacobs, G.C. The influence of IT management practice on IT use in large organizations. MIS Q. 1994, 18, 299-318. [CrossRef]

86. Noe, R.; Hollenbeck, J.; Gerhart, B.; Wright, P. Human Resources Management: Gaining a Competitive Advantage, 10th ed.; McGraw-Hill Education: New York, NY, USA, 2006.

87. Lado, A.A.; Wilson, M.C. Human resource systems and sustained competitive advantage: A competency-based perspective. Acad. Manag. Rev. 1994, 19, 699-727. [CrossRef]

88. Barney, J.B.; Wright, P.M. On becoming a strategic partner: The role of human resources in gaining competitive advantage. Hum. Resour. Manag. 1998, 37, 31-46. [CrossRef]

89. Hatch, N.W.; Dyer, J.H. Human capital and learning as a source of sustainable competitive advantage. Strateg. Manag. J. 2004, 25, 1155-1178. [CrossRef] 
90. Collins, C.J.; Clark, K.D. Strategic human resource practices, top management team social networks, and firm performance: The role of human resource practices in creating organizational competitive advantage. Acad. Manag. J. 2003, 46, 740-751.

91. Khandekar, A.; Sharma, A. Managing human resource capabilities for sustainable competitive advantage: An empirical analysis from Indian global organisations. Educ. Train. 2005, 47, 628-639. [CrossRef]

92. Hu, Q.; Huang, C.D. Aligning IT with firm business strategies using the balance scorecard system. In Proceedings of the 38th Annual Hawaii International Conference on System Sciences, Big Island, HI, USA, 6 January 2005; p. 230.

93. Reich, B.H.; Benbasat, I. Factors that influence the social dimension of alignment between business and information technology objectives. MIS Q. 2000, 24, 81-113. [CrossRef]

94. Nii, J.; Earl, M.; Ross, J. Eight imperatives for the new IT organization. Sloan Manag. Rev. Camb. 1996, 38, 43-55.

95. Teo, T.S.; Ang, J.S. Critical success factors in the alignment of IS plans with business plans. Int. J. Inf. Manag. 1999, 19, 173-185. [CrossRef]

96. Luftman, J.N.; Lewis, P.R.; Oldach, S.H. Transforming the enterprise: The alignment of business and information technology strategies. IBM Syst. J. 1993, 32, 198-221. [CrossRef]

97. Johnson, A.M.; Lederer, A.L. CEO/CIO mutual understanding, strategic alignment, and the contribution of IS to the organization. Inf. Manag. 2010, 47, 138-149. [CrossRef]

98. Chan, Y.E.; Reich, B.H. IT alignment: What have we learned? J. Inf. Technol. 2007, 22, 297-315. [CrossRef]

99. Raymond, L.; Croteau, A.-M. Manufacturing strategy and business strategy in medium-sized enterprises: Performance effects of strategic alignment. IEEE Trans. Eng. Manag. 2009, 56, 192-202. [CrossRef]

100. Kearns, G.S.; Lederer, A.L. A resource-based view of strategic IT alignment: How knowledge sharing creates competitive advantage. Decis. Sci. 2003, 34,1-29. [CrossRef]

101. Powell, T.C. Organizational alignment as competitive advantage. Strateg. Manag. J. 1992, 13, 119-134. [CrossRef]

102. Kearns, G.; Lederer, A. Strategic IT alignment: A model for competitive advantage. In Proceedings of the International Conference on Information Systems 2001, New Orleans, LO, USA, 16-19 December 2001; p. 2.

103. Brown, S.; Blackmon, K. Aligning manufacturing strategy and business-level competitive strategy in new competitive environments: The case for strategic resonance. J. Manag. Stud. 2005, 42, 793-815. [CrossRef]

104. Wright, P.; Kroll, M.; Pray, B.; Lado, A. Strategic orientations, competitive advantage, and business performance. J. Bus. Res. 1995, 33, 143-151. [CrossRef]

105. Davis, J.H.; Schoorman, F.D.; Mayer, R.C.; Tan, H.H. The trusted general manager and business unit performance: Empirical evidence of a competitive advantage. Strateg. Manag. J. 2000, 21, 563-576. [CrossRef]

106. Li, S.; Ragu-Nathan, B.; Ragu-Nathan, T.; Rao, S.S. The impact of supply chain management practices on competitive advantage and organizational performance. Omega 2006, 34, 107-124. [CrossRef]

107. Zikmund, W.; Babin, B.; Carr, J.; Griffin, M. Business Research Methods; South-Western College Pub: Cincinnati, OH, USA, 2009.

108. Sekaran, U.; Bougie, R. Theoretical framework in theoretical framework and hypothesis development. In Research Methods for Business: A Skill Building Approach; John Wiley \& Sons: Hoboken, NJ, USA, 2010; Volume 80.

109. Sekaran, U.; Bougie, R. Edisi 6. In Research Methods for Business; John Wiley \& Sons: Hoboken, NJ, USA, 2013.

110. Grindley, K. Information systems issues facing senior executives: The culture gap. J. Strateg. Inf. Syst. 1992, 1, 57-62. [CrossRef]

111. Pierce, A.C. The Effect of Business and Information Technology Strategic Alignment on Information Technology Investment Returns and Corporate Performance. Ph.D. Thesis, Nova Southeastern University, Broward, FL, USA, 2002.

112. Sabherwal, R.; Kirs, P. The alignment between organizational critical success factors and information technology capability in academic institutions. Decis. Sci. 1994, 25, 301-330. [CrossRef]

113. De Villiers, R. Sources of Sustainable Competitive Advantage for Businesses Operating in a Global Marketplace. Ph.D. Thesis, University of Pretoria, Pretoria, South Africa, 2001.

114. Nelson, K.M.; Cooprider, J.G. The contribution of shared knowledge to IS group performance. MIS Q. 1996, 20, 409-432. [CrossRef] 
115. Hamid, F.Z.A.; Atan, R. Corporate social responsibility by the Malaysian telecommunication firms. Int. J. Bus. Soc. Sci. 2011, 2, 198-208.

116. Nawanir, G. The Effect of Lean Manufacturing on Operations Performance and Business Performance in Manufacturing Companies in Indonesia. Ph.D. Thesis, Universiti Utara Malaysia, Changlun, Malaysia, 2016.

117. Chin, W.W.; Newsted, P.R. Structural equation modeling analysis with small samples using partial least squares. In Statistical Strategies for Small Sample Research; SAGE Publications: Thousand Oaks, CA, USA, 1999; Volume 1, pp. 307-341.

118. Wold, H. Causal flows with latent variables: Partings of the ways in the light of NIPALS modelling. Eur. Econ. Rev. 1974, 5, 67-86. [CrossRef]

119. Wold, H. Partial Least Squares, Encyclopaedia of Statistical Sciences, 6th ed.; Wiley: New York, NY, USA, 1985.

120. Ringle, C.; Wende, S.; Will, A. SmartPLS 2.0 (beta); University of Hamburg: Hamburg, Germany, 2005; Available online: http://www.smartpls.de (accessed on 28 March 2007).

121. Duarte, P.A.O.; Raposo, M.L.B. A PLS model to study brand preference: An application to the mobile phone market. In Handbook of Partial Least Squares; Springer: Berlin, Germany, 2010; pp. 449-485.

122. Chin, W.W.; Marcolin, B.L.; Newsted, P.R. A partial least squares latent variable modeling approach for measuring interaction effects: Results from a Monte Carlo simulation study and an electronic-mail emotion/adoption study. Inf. Syst. Res. 2003, 14, 189-217. [CrossRef]

123. Gerlach, R.W.; Kowalski, B.R.; Wold, H.O. Partial least-squares path modelling with latent variables. Anal. Chim. Acta 1979, 112, 417-421. [CrossRef]

124. Henseler, J.; Ringle, C.M.; Sinkovics, R.R. The use of partial least squares path modeling in international marketing. In New Challenges to International Marketing; Emerald Group Publishing Limited: Bingley, UK, 2009; pp. 277-319.

125. Hameed, W.U.; Basheer, M.F.; Iqbal, J.; Anwar, A.; Ahmad, H.K. Determinants of Firm's open innovation performance and the role of R \& D department: An empirical evidence from Malaysian SME's. J. Glob. Entrep. Res. 2018, 8, 29.

126. Hair, J.F.; Black, W.C.; Babin, B.J.; Anderson, R.E.; Tatham, R. Multivariate Data Analysis; Pearson Prentice Hall: Upper Saddle River, NJ, USA, 2010.

127. Hair Jr, J.F.; Hult, G.T.M.; Ringle, C.; Sarstedt, M. A Primer on Partial Least Squares Structural Equation Modeling (PLS-SEM); Sage Publications: Thousand Oaks, CA, USA, 2016.

128. Chin, W.W. The partial least squares approach to structural equation modeling. Mod. Methods Bus. Res. 1998, 295, 295-336.

129. McWilliams, A.; Siegel, D.S. Creating and capturing value: Strategic corporate social responsibility, resource-based theory, and sustainable competitive advantage. J. Manag. 2011, 37, 1480-1495. [CrossRef]

130. Smith, A.D. Making the case for the competitive advantage of corporate social responsibility. Bus. Strategy Ser. 2007, 8, 186-195. [CrossRef]

131. Li, N.; Toppinen, A. Corporate responsibility and sustainable competitive advantage in forest-based industry: Complementary or conflicting goals? For. Policy Econ. 2011, 13, 113-123. [CrossRef]

132. Byrd, T.A.; Turner, D.E. An exploratory analysis of the value of the skills of IT personnel: Their relationship to IS infrastructure and competitive advantage. Decis. Sci. 2001, 32, 21-54. [CrossRef]

133. Dehning, B.; Stratopoulos, T. Determinants of a sustainable competitive advantage due to an IT-enabled strategy. J. Strateg. Inf. Syst. 2003, 12, 7-28. [CrossRef]

134. Porter, M.E. Competitive Advantage of Nations: Creating and Sustaining Superior Performance; Simon and Schuster: New York, NY, USA, 2011.

135. Chan, L.L.; Shaffer, M.A.; Snape, E. In search of sustained competitive advantage: The impact of organizational culture, competitive strategy and human resource management practices on firm performance. Int. J. Hum. Resour. Manag. 2004, 15, 17-35. [CrossRef]

(C) 2019 by the authors. Licensee MDPI, Basel, Switzerland. This article is an open access article distributed under the terms and conditions of the Creative Commons Attribution (CC BY) license (http://creativecommons.org/licenses/by/4.0/). 